\title{
Islamisasi Ilmu Pengetahuan: Pergulatan Pemikiran Cendekiawan Kontemporer
}

\author{
Mustofa Hilmi ${ }^{1 凶}$ \\ ${ }^{1}$ Universitas Islam Negeri Walisongo Semarang \\ $\triangle$ mustofa.hilmi@walisongo.ac.id
}

Riwayat naskah:

Diterima: 6 Maret 2020

Disetujui: 6 Desember 2020

Diterbitkan: 18 Desember 2020

\begin{abstract}
The debate of experts regarding the perspective of science in Islam is still ongoing. The paradigm of the islamization of science emerged due to the feeling of the Muslims backwardness from advanced Western civilization. This study aims to elaborate on various views of Muslim scholars on the concept of islamization of science. Employing a literature study using descriptive qualitative research, this study indicates that some religious experts assume that there should be no dichotomy between religious and science in general. Religion must be the foundation of every science because they believe that everything, including science, is sourced from Allah. In essence, there is no separation between religion and every scientific discipline. But the Western thinkers have other views that they focus on the development of science in a positive-empirical aspect. The object of knowledge must be observable. They do not recognize the source and method of development of science in which Muslims use the senses, reason, and intuition. The author argues that somebody must support the idea of the islamization of science to restore knowledge according to its nature. The advancement of modern science must lead a Muslim to increase faith in Allah.
\end{abstract}

Keywords: intuition; islamization; science; secular

Abstrak: Perdebatan para pakar mengenai cara pandang konsep ilmu pengetahuan dalam Islam masih belum berakhir. Paradigma islamisasi ilmu pengetahuan muncul di tengah kondisi tertinggalnya umat Islam dari peradaban Barat yang sudah maju. Tulisan ini bertujuan untuk mengelaborasi berbagai pandangan cendekiawan kontemporer tentang konsep islamisasi ilmu pengetahuan. Kajian ini merupakan studi kepustakaan dengan menggunakan jenis penelitian kualitatif deskriptif. Hasil penelitian menunjukkan bahwa agamawan menganggap tidak boleh ada dikotomi antara ilmu pengetahuan agama dan umum. Agama harus menjadi landasan setiap ilmu pengetahuan yang ada karena mereka meyakini bahwa segala sesuatu yang ada termasuk ilmu pengetahuan adalah bersumber dari Allah Swt., sehingga pada hakikatnya tidak ada sekularisme antara agama dengan setiap cabang disiplin ilmu pengetahuan. Namun para pemikir Barat memiliki tinjauan lain. Mereka hanya menitikberatkan pengembangan ilmu pengetahuan secara positif-empiris. Objek pengetahuan harus dapat diobservasi. Mereka tidak mengakui sumber dan metode pengembangan ilmu pengetahuan muslim yang menggunakan panca indra, akal, dan intuisi. Penulis berpendapat gagasan islamisasi ilmu pengetahuan ini harus didukung sebagai upaya mengembalikan ilmu sesuai fitrahnya. Kemajuan sains modern harus mengantarkan umat manusia pada peningkatan iman kepada Allah Swt.

Kata kunci: intuisi; ilmu pengetahuan; islamisasi; sekular

P-ISSN 1907-1191 E-ISSN 2540-9204 @ 2020 pada penulis.

Diterbitkan oleh LP2M INSURI Ponorogo, artikel jurnal ini dapat diakses secara terbuka dengan lisensi CC-BY-SA DOI: 10.37680 /adabiya.v15i02.268 


\section{Pendahuluan}

Perkembangan ilmu pengetahuan dan teknologi saat ini semakin menandai kemajuan yang telah dicapai Barat. Era Revolusi Industri yang sudah memasuki 4.0 meneguhkan Barat sebagai kiblat peradaban dunia. Perkembangan pesat disiplin ilmu di berbagai bidang baik ilmu alam, ilmu eksakta, ilmu humaniora, teoritis, maupun praktis menjadi standar masyarakat dunia saat ini. Perkembangan teknologi digital, kepemilikan big data, intelegensi buatan, teknologi nano, dan robotik telah menjadi tren yang merajai dunia.

Kenyataan ini telah membawa masyarakat dalam kondisi ambivalen. Pesatnya perkembangan ilmu pengetahuan tidak hanya membawa sisi positif, namun juga dampak negatif seperti gaya hidup konsumtif, cyber crime, tingginya investasi SDM, eksploitasi sumber daya alam, dan manusia dan sebagainya. Kenyataan tersebut memantik sebagian ilmuwan khususnya para pakar muslim untuk melakukan kritik terhadap perkembangan yang ada. Meski tidak sedikit yang menganggap kritikan tersebut sebagai suara minor, sinis, bahkan dipandang sebelah mata. Akan tetapi hal tersebut tidak menyurutkan mereka untuk melakukan kritik serta sisi negatif ilmu pengetahuan dan teknologi.

Menurut Al-Faruqi, segala sesuatu yang ada di dunia termasuk ilmu pengetahuan dan teknologi adalah bersumber dari Tuhan Yang Maha Esa. Perkembangan peradaban tidak boleh lepas akan kesadaran akan tauhidullah. Sinergi antara dunia dan akhirat. ${ }^{1}$ Oleh karena itu, konsekuensi logis pemahaman ini yakni setiap disiplin ilmu pengetahuan pada akhirnya harus bermuara pada bertambahnya keyakinan (keimanan) kepada Allah Swt. Namun realitas peradaban yang dibangun tidak menunjukkan hal tersebut. Kehadiran Tuhan absen dalam ilmu pengetahuan yang telah dikembangkan Barat. Bahkan pada tahap tertentu, kepemimpinan Barat tersebut dianggap sebagai bentuk baru penjajahan atas dunia Islam. Menghadapi keadaan yang demikian itu, para ilmuwan muslim mencoba mencari sebab-sebab utama penyebab ketertinggalan mereka.

Secara garis besar, terdapat tiga respon ilmuwan muslim dalam menyikapi ketertinggalan umat Islam dalam pengembangan ilmu pengetahuan yaitu: ${ }^{2}$

Pertama, asumsi sebagian pakar yang menyatakan bahwa terdapat pemisahan yang jelas antara ilmu pengetahuan dan agama. Tidak ada semangat transendental dalam sains sehingga menimbulkan banyak mudarat dari pada manfaat. Perkembangan sains modern lebih berlandaskan pandangan ateistik, empiristik, materialistik, bahkan hedonistik. Ilmu pengetahuan sekular ini tidak dapat diterima. ${ }^{3}$ Para sarjana muslim khawatir dengan mempelajari ilmu sekular akan semakin menjauhkan diri dari Allah SWT. Padahal di sisi lain, justru perkembangan Islam akan diperoleh dengan kembali pada petunjuk yang ada dalam kitabullah dan Hadis Nabi saw serta turats Islam di zaman klasik. Menjadikan ajaran Islam sebagai sumber otoritatif dalam pengembangan ilmu pengetahuan.

Kedua, asumsi yang menyatakan bahwa Barat meletakkan ilmu pengetahuan dalam posisi netral. Ilmu bersifat universal dan objektif. Menurut seorang fisikawan muda Universitas Qiad-i-

\footnotetext{
1 Aris Try Andreas Putra, "Konsep Pemikiran Ismail Raji Al-Faruqi (Dari Tauhid Menuju Integrasi Ilmu Pengetahuan di Lembaga Pendidikan”, Zawiyah : Jurnal Pemikiran Islam Volume 6 Nomor 1 Juli 2020), 22.

2 Abuddin Nata, Metodologi Studi Islam (Jakarta: PT Raja Grafindo Pustaka, 2016), 405-406.

${ }^{3}$ Umi Hanifah, "Islamisasi Ilmu Pengetahuan Kontemporer (Konsep Integrasi keilmuan Di UniversitasUniversitas Islam Indonesia,” TADRIS: Jurnal Pendidikan Islam 13, no. 2 (2018): 273-94.
} 
azam di Pakistan, Parvez H menegaskan bahwa tidaklah benar pembagian sebagaian pakar bahwa ilmu pengetahuan terpisah menjadi dua yakni ilmu duniawi dan samawi. Segala usaha menjadikan ilmu islami hanya akan mengalami kegagalan. ${ }^{4}$ Oleh karena itu, seseorang dapat menerima ilmu pengetahuan sebagaimana adanya tanpa sangsi dan rasa khawatir.

Ketiga, asumsi bahwa Barat mengembangkan ilmu pengetahuan yang bersifat materialis dan sekular. Terdapat pemisahan nyata antara ilmu dengan agama. Semangat keagamaan tidak menjadi nilai dasar pengetahuan tersebut. Ia hanya menjadi pemuas hawa nafsu dan kepentingan ekonomi kapitalis. Jika orientasi pengetahuan tidak segera diarahkan kembali ke jalan yang benar maka tidak menutup kemungkinan seseorang yang mempelajarinya secara lambat laun akan menjauh dari agama. Pengetahuan tersebut tidak bersifat netral. Subjektivitas seorang peneliti ikut mewarnai hasil penelitian. Ia memberikan kerangka konseptual berupa gagasan, pandangan, pemikiran, budaya, dan falsafah serta menyaring sesuai dengan apa yang diketahui. Dalam konteks ilmu modern maka ilmu tersebut sedikit banyak mencerminkan kehidupan pengalaman Barat. Umat muslim dapat menerima ilmu pengetahuan ini dengan cara melakukan proses islamisasi terlebih dahulu.

Berdasarkan penjelasan singkat ketiga pandangan di atas, maka penulis melakukan eksplorasi lebih lanjut tentang pandangan islamisasi ilmu pengetahuan. Dalam artikel ini, penulis akan menjelaskan lebih lanjut mengenai pandangan beberapa pakar muslim baik yang pro maupun yang kontra dalam menyikapi islamisasi ilmu pengetahuan dan berbagai argumentasi tentangnya. Tulisan ini bertujuan untuk mengetahui gambaran konsep islamisasi ilmu pengetahuan yang telah digagas oleh para pakar muslim.

Kajian dalam tulisan ini adalah studi kepustakaan (library research) dengan jenis penelitian kualitatif deskriptif. Sumber data yang digunakan dalam kajian ini adalah pemikiran-pemikiran tokoh cendekiawan yang telah ditulis dalam berbagai literatur baik jurnal, proceeding, dan buku maupun sumber daring yang relevan dengan topik Islamisasi Ilmu Pengetahuan. Setelah berbagai data terkumpul, penulis akan melakukan reduksi data (data reduction). Pada tahap ini, data akan dipilah dan dipilih sesuai dengan pokok kajian yang telah ditentukan. Kemudian penulis mengorganisir data dengan menyusunnya menjadi pola tertentu untuk disajikan menjadi sebuah pemikiran yang mudah dipahami (penyajian data). Langkah terakhir, penulis akan menarik kesimpulan dari berbagai pemikiran yang telah dikemukakan oleh para ahli tersebut. ${ }^{5}$

\section{Sejarah Kemunculan Islamisasi Ilmu Pengetahuan}

Pada dasarnya, proses islamisasi di segala lini kehidupan termasuk ilmu pengetahuan sudah diperkenalkan semenjak Islam lahir. Semangat tersebut telah ditegaskan dalam QS Al-Alaq ayat 1-5:

"Bacalah dengan (menyebut) nama Tuhanmu yang Menciptakan (1), Dia Telah menciptakan manusia dari segumpal darah (2). Bacalah, dan Tuhanmu lah yang Maha pemurah (3), Yang mengajar (manusia) dengan perantaraan kalam (4), Dia mengajar kepada manusia apa yang tidak diketahuinya (5)'”.

${ }^{4}$ Mulyadhi Kartanegara, "Islamisasi Ilmu Pengetahuan dan Telaah Kritis Terhadap Epistemologi Barat," Jurnal Refleksi 1, no. 3 (1999).

${ }^{5}$ Sugiyono, Memahami Penelitian Kualitatif (Bandung: Alfabeta, 2016), 14. 
Ayat pertama surat di atas, tidak menyampaikan objek yang diperintahkan untuk membaca. Dalam kaidah bahasa Arab menyatakan bahwa apabila terdapat sebuah objek yang seharusnya ada setelah kata kerja namun tidak disebut maka makna yang dimaksud adalah objek bersifat umum. Kata kerja tersebut menjangkau semua segala sesuatu yang dapat dijadikan objek. ${ }^{6}$ Lebih lanjut ayat tersebut memerintahkan manusia untuk tidak hanya 'membaca'. Allah menghendaki manusia melakukan pembacaan secara menyeluruh pada alam semesta. Membaca adalah lambang. Ia dapat bermakna aktif maupun pasif sehingga melalui makna tersurat maupun tersirat, Al-Qur'an ingin menyatakan "Bacalah demi Tuhanmu, bergeraklah demi Tuhanmu, bekerjalah demi Tuhanmu”. Begitu pula ketika seseorang berhenti bergerak maka hendaklah didasari pada Bismi Rabbik. Tuhan menjadi alasan utama dalam mempelajari, mengkaji, dan mengembangkan ilmu pengetahuan. Tidak ada yang bebas nilai karena setiap segala yang ada tidak dapat lepas dari kuasa-Nya.

Allah maha pengasih dan penyayang kepada setiap makhluk-Nya. Karena kedua sifat itulah manusia dituntun untuk mempelajari tanda-tanda kebesaran-Nya melalui ayat-ayat Qauliyah dan ayat-ayat Kauniyah. Ayat Qauliyah dapat ditemukan dengan mempelajari sumber ajaran Islam sedangkan ayat Kauniyah dapat ditemukan dengan mempelajari fenomena dan kejadian alam semesta. Dengan pemahaman dasar ini, manusia akan sadar bahwa pemahaman umum dan pengalaman empiris bukan merupakan satu-satunya sumber ilmu pengetahuan.

Tahun 1930-an, seorang pemikir muslim bernama Muhammad Iqbal mengemukakan pentingnya peradaban Islam melakukan rekonstruksi ilmu pengetahuan. Ia menyadari bahwa tidak ada ruh ilahiyah dalam ilmu yang dikembangkan Barat. Tidak terdapat unsur ketuhanan atau sengaja terdapat pemisahan antara duniawi dan ukhrawi. Oleh karena itu, ia menggagas pentingnya umat Islam melakukan konversi atau rekonstruksi ilmu pengetahuan modern. Namun Muhammad Iqbal tidak menjelaskan langkah atas gagasan tersebut. Belum terdapat penelitian secara sistematis terhadap problem ontologis, epistemologis, dan aksiologis ilmu pengetahuan barat sekular itu, sehingga gagasan Muhammad Iqbal baru dalam tahap ide tanpa konsep dan metodologi untuk melakukan proses islamisasi ilmu pengetahuan. ${ }^{7}$

Ismail Raji al-Faruqi merupakan tokoh yang pertama kali menggagas islamisasi ilmu pengetahuan. Ilmuwan asal Palestina yang bertempat tinggal di Amerika. Ide tersebut dikembangkan bersamaan dengan berdirinya sebuah lembaga penelitian International Institute of Islamic Thought (IIIT). Lembaga ini berkedudukan di Philadelphia yang kemudian pindah ke Hemdon, Virginia. Namun di sisi lain, terdapat cendekiawan muslim yang juga mengembangkan ide yang sama yakni Syekh Naquib al-Attas, Malaysia. Kerja akademis Naquib didukung pemerintah Malaysia (pada saat itu Perdana Menteri Anwar Ibrahim) dengan mendirikan sebuah lembaga bernama International Institute of Islamic Thought and Civilization pada $1987 .{ }^{8}$

Awalnya al-Faruqi merumuskan pemikiran pada dua hal pokok yaitu Islam dan Arab. Dalam kajiannya tentang Arab, ia telah menuangkan pemikiran dalam karya yang berjudul "On Arabism: Urubah and Religion" yang terdiri dari 4 jilid. Namun pada perkembangan berikutnya, ia lebih menitikberatkan perhatian studi Islam melalui gerakan advokasi politik, kajian akademis, maupun diskursus ilmiah tentang urgensi Islam dalam setiap segi kehidupan. Pada penghujung

\footnotetext{
${ }^{6}$ M Quraish Shihab, Tafsir Al-Misbah: Pesan, Kesan Dan Keserasian Al-Quran (Jakarta: Lentera Hati, 2002).

${ }^{7}$ Salafudin, Islamisasi Ilmu Pengetahuan, (Pekalogan : Forum Tarbiyah Vol. 11 no. 2, 2013) 201

${ }^{8}$ Naquib Al-Attas, Islam dalam sejarah dan Kebudayaan Melayu, (Bandung : Mizan, 1990), 10-11
} 
tahun 1960-an, ia memberikan perhatian yang cukup besar dengan memperkenalkan Islam sebagai agama logis dan ilmiah, berkemajuan dan sempurna. Ia tampil sebagai tokoh pembaharu yang meletakkan ajaran agama Islam sebagai dasar pijakan dalam bersikap dan bertindak. Islam adalah way of life yang lengkap dan komprehensif. Al-Faruqi mengoreksi cara pandang umat Islam saat ini yang membagi ilmu menjadi dua, yakni ilmu pengetahuan umum dan agama. Baginya, pemisahan ini fatal karena memisahkan agama dari ilmu pengetahuan. Al-Faruqi telah menuangkan gagasan islamisasi ilmu pengetahuan secara lengkap dalam karyanya yang berjudul The Islamization of Knowledge. Gagasan ini cukup menyita perhatian intelektual muslim pada tahun 1982 dalam seminar perdana yang diselenggarakan di Islamabad, Pakistan. ${ }^{9}$

Program pendahuluan dari risalah di atas, al-Faruqi menulis bahwa IIIT menawarkan kepada cendekiawan muslim seluruh dunia hadiah yang abadi dan unik yang telah dipersembahkan dalam dekade pertama abad ke 15 Hijriyah. Al-Faruqi menegaskan bahwa itulah saatnya seorang umat Islam yang memikirkan pentingnya islamisasi ilmu pengetahuan, memahami syarat-syaratnya dan mendiskusikan langkah-langkah yang diperlukan. Dengan kondisi di atas Al-Faruqi berupaya menjelaskan pada dunia Islam akan potensi konflik antara paradigma keilmuan Timur dan Barat. Kondisi ini harus segera diatasi untuk menghindari kesalahpahaman yang berkelanjutan dan konflik ideologi antar peradaban. Al-Faruqi menginginkan sistem pendidikan Islam kembali berkembang secara sinergis dengan perkembangan pengetahuan dan teknologi saat ini. ${ }^{10}$

Pakar lain yang membawa ide islamisasi ilmu pengetahuan adalah seorang tokoh dari Singapura yakni Syed Muhammad al Naquib bin Ali bin Abdullah bin Muhsin al-Attas. Ia lahir pada tanggal 5 September 1931 di Bogor, Jawa Barat, Indonesia, meski merupakan cendekiawan muslim dan filsuf yang berkebangsaan Malaysia. Beberapa bidang ilmu pengetahuan yang ia kuasai antara lain Sejarah, Metafisika, dan Teologi. Kemampuannya dalam menganalisis pemikiran dan peradaban Islam telah membawa pada sebuah ide tentang islamisasi ilmu pengetahuan. ${ }^{11}$

Pemikiran antara Al-Attas dengan Al-Faruqi dapat ditemukan setelah tahun 1960-an. Kedua pakar muslim tersebut memperkenalkan proyek islamisasi ilmu pengetahuan. Pada tahun 1974 di Malaysia kepada sivitas akademika dan para ilmuwan di sana. Pada pertemuan tersebut Al-Faruqi menyimak pandangan Al-Attas tentang beberapa ide yang sebelumnya belum ia ketahui seperti peluang dan tantangan serta implikasi islamisasi ilmu pengetahuan tersebut. Diskusi kedua tokoh pembaharu ini terus berlanjut dalam beberapa kesempatan. Gagasan-gagasan Al-Attas banyak mempengaruhi pemikiran Al-Faruqi yang pada saat itu menjabat sebagai presiden Association of Muslim Social Scientist (AMSS). Lebih lanjut, Al-Faruqi mengundang Al-Attas menjadi pembicara dalam simposium tentang "Islam dan Pembangunan" yang diadakan di Philadelphia, Amerika Serikat, pada tanggal 22-24 April 1976. Al-Faruqi sangat mengapresiasi sumbangan

${ }^{9}$ Zuhdiyah, “Islamisasi Ilmu Ismail Raji Al-Faruqi”, Tadrib : Jurnal Pendidikan Agama Islam 2, no. 2 (2016), 13

${ }^{10}$ Wan Mohammad Nor Wan Daud, Filsafat Pendidikan Islam, Syed M. Naquib AlAttas, terj. Hamid Fahmi dalam Mohammad Muchlis Solichin, "Islamisasi Ilmu Pengetahuan dan Aplikasinya Dalam Pendidikan Islam," TADRIS: Jurnal Pendidikan Islam 3, no. 1 (2008).

${ }^{11}$ Irma Nivayani, "Islamisasi Ilmu Pengetahuan Menurut Pandangan Syed M. Naquib Al-Attas dan Impikasi Terhadap Lembaga Pendidikan International Institute of Islamic Thought Civilization (ISTAC)", Jurnal AlMuta'aliyah 1 no. 1 (2017), 76 
pemikiran dan langkah-langkah yang diambil Al-Attas untuk mewujudkan islamisasi ilmu pengetahuan di masa mendatang. ${ }^{12}$

\section{Berbagai Pendapat Mengenai Islamisasi Ilmu Pengetahuan}

Al-Qur'an telah menekankan umat Islam untuk menuntut ilmu pengetahuan. Bagi siapapun yang telah mencari ilmu maka ia akan mendapatkan derajat tinggi di sisi Allah Swt. yang termaktub dalam surat Al-Mujadilah: 11. Bahkan dalam ayat lain, Al-Qur'an menegaskan perbedaan yang jelas antara tidak sama orang yang berpengetahuan dengan yang tidak berpengetahuan, yaitu dalam surat Az Zumar: 9. Kedua ayat ini mengisyaratkan kepada manusia agar memiliki ilmu pengetahuan sehingga dapat mengambil pelajaran dan peristiwa yang terjadi di sekitarnya. Melalui ayat ini, Islam mengajarkan untuk selalu menuntut ilmu pengetahuan, lebih lanjut, AlQur'an tidak menyatakan adanya rincian pembagian ilmu. Agama merupakan totalitas integral dalam kehidupan dunia yang tidak dapat dipisahkan. ${ }^{13}$

Secara fitrah, manusia adalah makhluk yang senantiasa berupaya mencari kebenaran. Allah Swt. telah memberi anugerah berupa akal dan hati. Para cendekiawan muslim telah mencoba merumuskan posisi ilmu pengetahuan dalam konsep Islam. Dalam hal ini, Al-Ghazali telah menetapkan tiga kriteria analisis yaitu ${ }^{14}$ :

a. Sumber

i. Pengetahuan berasal dari wahyu. Pengetahuan ini diberikan Allah Swt. kepada hamba pilihannya seperti nabi dan rasul. Kebenaran bersifat absolut karena didasarkan pada keimanan. Dalam hal ini, keyakinan atas wahyu merupakan bentuk pengakuan akan kelemahan manusia kepada Tuhan yang Maha Esa.

ii. Pengetahuan yang tidak berasal dari wahyu. Rasio, observasi, dan akulturasi menjadi sumber pokok dalam pencarian ilmu pengetahuan. Manusia menyusun pemahaman dalam suatu sistem yang terstruktur atas objek yang diselidikinya baik berupa alam, manusia, maupun agama.

b. Kewajiban

i. Pengetahuan yang bersifat fardhu 'ain (diwajibkan untuk setiap individu). Pengetahuan ini sangat penting bagi yang bersangkutan karena terkait kewajiban mendasar dirinya sebagai hamba yang harus taat kepada Tuhannya. Lebih dari itu, pengetahuan ini demi kebaikan individu seperti dalam masalah etika sosial, kesusilaan, dan hukum sipil.

ii. Pengetahuan yang bersifat fardhu kifayah (diwajibkan untuk sebagian kelompok individu). Kelompok masyarakat yang memiliki peran penting dalam perputaran kehidupan seperti petani, dokter, arsitektur, dan teknisi mesin.

${ }^{12}$ Wan Mohd Nor Wan Daud, Filsafat dan Praktik Pendidikan Islam, Syed M. Naquib al-Attas (Bandung : Mizan, 2003), 934

${ }_{13}$ Fitri Wahyuni, "Islamisasi Ilmu Pengetahuan (Upaya Mengurai Dikotomi Ilmu Pengetahuan Dalam Islam)," QALAMUNA: Jurnal Pendidikan, Sosial, Dan Agama 10, no. 02 (2018). https://doi.org/10.5281/zenodo.3559251

${ }^{14}$ Ziauddin Sardar, Sains,Teknologi,dan Pembangunan di Dunia Islam (Bandung : Penerbit Pustaka, 1989), 


\section{c. Fungsi Sosial}

i. Ilmu yang harus dihargai. Ilmu jenis pertama ini memiliki nilai manfaat sehingga tidak boleh diabaikan. Boleh jadi keberadaannya memiliki keterkaitan erat dan penting dengan berbagai aktivitas kehidupan.

ii. Ilmu yang harus dihindari. Ilmu jenis kedua ini adalah sebuah ilmu yang tidak memiliki nilai manfaat kepada diri sendiri dan orang lain. Bahkan jika penggunaannya tidak tepat, maka dapat menimbulkan mudarat. Beberapa ilmu pengetahuan yang masuk kategori ini adalah terapi aversi, magis, astrologi, ilmu perang, teknis genetika, dan studi tentang penyiksaan.

Di sisi lain, terdapat juga kelompok intelektual muslim yang mengatakan bahwa semua ilmu pengetahuan bersifat netral. Tidak terdapat pemisahan ilmu menjadi ilmu pengetahuan modern dan Islam. Kajian-kajian ilmu pengetahuan bersifat objektif. Ia menjelaskan materi keilmuan sesuai dengan keadaan sebenarnya tanpa dipengaruhi oleh pendapat atau pandangan pribadi. ${ }^{15}$ Pakar Islamic Studies Universitas Sorbonne Perancis, Mohammed Arkoun, menegaskan bahwa upaya islamisasi ilmu pengetahuan merupakan sebuah kesalahan. Secara tidak sadar, para cendekiawan muslim akan terjebak pada pemahaman yang keliru yakni simplifikasi agama. Langkah ini dinilai sebagai usaha yang kontra produktif karena hanya menganggap Islam sebagai ideologi. ${ }^{16}$

Selaras dengan hal itu, Usep Fathuddin mengatakan bahwa umat Islam tidak perlu melakukan langkah tersebut. Islamisasi ilmu bukanlah kerja ilmiah apalagi kreatif. Islamisasi ilmu membawa seseorang untuk bersikap pasif. Proses tersebut baru dapat dilakukan setelah orang lain menghasilkan karya. ${ }^{17}$ Menurut Fathuddin, bahwa sampai saat ini islamisasi ilmu pengetahuan selalu didasarkan pada anggapan tentang dua kebenaran yang berbeda, yakni kebenaran ilmu dan kebenaran agama. Padahal jika dilihat dari sisi sejarah, permasalahan antara agama dan ilmu pengetahuan tidak pernah ada. Bahkan justru sebaliknya, puncak kejayaan umat Islam terjadi ketika menyatunya kedua hal tersebut. ${ }^{18}$ Hal ini senada dengan gagasan Amin Abdullah tentang paradigma integratif-interkonektif merupakan upaya yang sangat baik dalam mengembangkan pemikiran dan ilmu agama sekaligus. Gagasannya memiliki poin penting untuk mengimbau bahwa semua disiplin ilmu harus saling berinteraksi, untuk merespon dinamika peradaban yang terus berkembang. ${ }^{19}$

Kuntowijoyo mengatakan bahwa secara epistemologis, Islam sudah memiliki bangunan keilmuan tersendiri yakni strukturalisme transendental yang secara universal sudah mencakup ilmu-ilmu alam, kemanusiaan, dan agama. Hal ini mengindikasikan bahwa keilmuan Islam pada hakikatnya selalu sesuai dengan tantangan dan perubahan zaman tanpa kehilangan identitas agama yang paripurna sehingga islamisasi ilmu pengetahan tidak diperlukan. ${ }^{20}$

\footnotetext{
${ }^{15}$ Mulyadhi Kartanegara, Mengislamkan Nalar: Sebuah Respon Terhadap Modernitas (Erlangga, 2007), 2-3.

${ }^{16}$ Muslih Usa dalam Nata, Metodologi Studi Islam.

${ }^{17}$ Usep Fathuddin, Muslich Hasbullah dalam Nata.

18 Nata.

${ }^{19}$ Febri Hijroh Mukhlis, "Integrasi-Interkoneksi keilmuan Prof. Amin Abdullah: Kesalingterkaitan Antara Ilmu-Ilmu Agama Dan Science,” Al-Adabiya: Jurnal Kebudayaan Dan Keagamaan 13, no. 01 (September 3, 2018): 78-101, https://doi.org/10.37680/adabiya.v13i01.5.

${ }^{20}$ Kuntowijoyo, Islam sebagai Ilmu Epitemologi, Metodologi, dan Etika, (Yogyakarta : Tiara Wacana, 2006),
} 39. 
Di sisi lain, terdapat cendekiawan muslim yang menyatakan dukungan terhadap inisiasi konsep integrasi kelimuan. Hal ini didasarkan pada perbedaan epistemologi sains Barat dengan Islam. Perbedaan cara pandang dunia antara barat dan timur ini tidak mudah diaplikasikan dan realitas kehidupan sosial. Masyarakat Barat meyakini bahwa kebenaran dalam kehidupan manusia dan alam semesta adalah segala sesuatu yang dapat dibuktikan melalui indra. ${ }^{21}$ Barat membatasi metodologi penelitian indrawi (sensible) merupakan satu-satunya sumber kebenaran. Sebuah metode yang didasarkan pada pengalaman-pengalaman indrawi dan proses logika murni guna memilih, memutuskan, dan memberi kesimpulan.

Pandangan Barat tersebut bersumber pada paradigma positivisme. Sebuah aliran filsafat yang hanya mengukur nilai kebenaran dengan cara observasi dan dibuktikan secara positifempiris. Segala fenomena yang tidak dapat diindra maka mereka anggap bukan sebagai realitas nyata (non real). Hal itu pada akhirnya membawa seseorang untuk menolak objek-objek nonempiris dan meragukan status keilmuan yang menjadikan objek tersebut sebagai objek material dan formal. Lingkup dan klasifikasi ilmu modern meliputi pemikiran, budaya, sejarah, materi, kehidupan dan alam.

Di pihak lain, sebagian umat Islam dalam ilmu pengetahuan terlalu berorientasi pada religiusitas dan spiritualitas dengan kurang memberikan perhatian memadai atas urgensi ilmuilmu modern yang dianggap sekular. Bahkan terdapat kecenderungan sikap defensif dengan menyatakan larangan terhadap segala bentuk inovasi terhadap hasil ijtihad intelektual muslim abad pertengahan. Sikap seperti ini dapat dimaknai sebagai bentuk kejumudan dan ketidakmampuan umat Islam dalam membaca, memahami, serta menelaah sumber ajaran agama. Padahal sebagaimana diketahui bahwa perubahan adalah sebuah keniscayaan, sehingga umat Islam harus memiliki sikap tanggap dan progresif atas perkembangan zaman agar Islam dapat selalu kontekstual dalam menjawab tantangan zaman.

Dampak negatif atas sikap 'kepala batu' sebagian ilmuwan muslim sendiri sesungguhnya tidak kalah memprihatinkan dibanding kondisi sains modern. Fakta menunjukkan bahwa umat Islam bersikap konservatif-statis. Kondisi ini pada akhirnya menimbulkan jurang pemisah antara wahyu dan akal; pikiran dan tindakan; serta pemikiran dan kultur, sehingga menimbulkan kemandekan ilmu pengetahuan di kalangan umat Islam. ${ }^{22}$

Dalam rangka menjembatani kesenjangan yang ada, Al-Faruqi mencoba melakukan analisa pemikiran antara sains modern dan Islam. Ia berpendapat bahwa model pengetahuan Islami tidak hanya didasarkan pada ruang lingkup pada benda-benda fisik indrawi (sensible/mahsusah), tetapi juga metafisik (intelligibles/ma'qulah) yakni realitas yang ada di luar dunia indrawi. Sebuah kebenaran yang dapat dibuktikan melalui logika inferensial, intuisi, dan keyakinan baik langsung maupun presensial. Dalam khazanah Islam, selain pengalaman indrawi, wahyu juga menjadi rujukan pengembangan ilmu pengetahuan. Al-Qur'an adalah kitab suci yang bersifat syummul. Dalam beberapa ayat, ia menganjurkan umatnya untuk senantiasa berpikir dan mempelajari segala ciptaan Allah Swt. ${ }^{23}$

\footnotetext{
${ }^{21}$ Harun Nasution, Ensiklopedi Islam Indonesia Vol I, (Jakarta : Djambatan, 1992),242

${ }^{22}$ Ismail Raji Al-Faruqi, Islam and Knowledge, Al-Faruqi Concept of Religion in Islamic Thought, (New York I.B Tauris, 2012), 43.

${ }^{23}$ Taufik Hidayat, Konsep Berpikir (Al-Fikr) Dalam Al-Quran dan Implikasinya Terhadap Pembelajaran PAI di Sekolah (Studi Tematik tentang Ayat-Ayat yang Mengandung Term al-Fikr), Tarbawy 3, no.1, 2016, 2
} 
Islam sama sekali tidak mengenal pemisahan dalam ilmu pengetahuan. ${ }^{24} \mathrm{Kalangan}$ muslim berpendapat tidak ada perbedaan kebenaran antara entitas fisik dan metafisik. ${ }^{25}$ Mengorientasikan pengetahuan pada hanya pada empirisme tanpa memperhitungkan metafisik maka yang akan terjadi adalah gejala desakralisasi ilmu. ${ }^{26}$ Oleh karena itu, ruang lingkup ilmu islami tidak hanya pada segala hal yang bersifat fisik namun juga metafisik seperti Tuhan, malaikat, hari akhir, kiamat, qadha, qadar, alam barzakh, hari kebangkitan, padang mahsyar, hisab, mizan, surga, dan neraka. Al-Kindi, filosof pertama muslim menyatakan bahwa ilmu harus meliputi bukan hanya dunia fisik tetapi juga dunia metafisik. ${ }^{27}$

Selain epistemologi, terdapat perbedaan metode dalam ilmu pengetahuan Islam dan sains Barat. Ilmuwan muslim merumuskan terdapat tiga pendekatan yang digunakan untuk melihat realitas yakni intuisi, rasio, dan pengalaman (indra). Namun di pihak lain, Barat hanya mengakui bahwa kebenaran hanya dapat dipastikan melalui pengalaman. Kenyataan ini membawa konsekuensi dimana Barat hanya menggunakan metode observasi sebagai sumber tunggal dalam menilai kebenaran. Rasio memang digunakan, namun hanya sebatas sarana untuk mencapai proses pemahaman dan pengambilan kesimpulan. Akal tidak difungsikan sebagai sumber utama dalam melihat kenyataan.

Beda halnya dengan ilmuwan Barat, ilmuwan Timur tidak hanya menjadikan observasi sebagai sumber utama keabsahan data, namun juga logika (burhani) dan intuisi ('irfani). Hal ini bermakna bahwa cendekiawan muslim tidak hanya menitikberatkan perhatian pada persepsi indrawi dalam pemaknaan hakikat kebenaran, namun juga aktualisasi rasio dan keyakinan hati. Perbedaan metodologis ini menyebabkan ilmu-ilmu sains modern barat sulit diterapkan untuk memahami realitas komunitas muslim karena sudut pandang keilmuan yang berbeda. ${ }^{28}$

Khazanah Islam meletakkan rasio sebagai alat untuk menilai dan merumuskan realitas. Konsep ini pada akhirnya melahirkan sebuah metode yang disebut sebagai rasional-demonstratif (burhani) atau diskursif. Sebagaimana indra yang dapat menguak hakikat kebenaran, maka penggunaan rasio yang tepat dan optimal dalam melihat realitas dapat melahirkan sebuah kesimpulan yang bisa dipertanggungjawabkan. Rasio dapat digunakan untuk menangkap polapola pemikiran baik yang terdiri dari premis mayor, premis minor, sampai menarik konklusi dari permasalahan yang ada. Melalui metode ini, seseorang dapat menyadari dan memahami realitas metafisika melalui pemahaman fisik yang ada di sekelilingnya.

Selain indra dan rasio, sarjana muslim juga menggunakan metode intuitif ('irfani). Meskipun indra dan rasio memiliki kemampuan yang sama dalam melihat realitas kehidupan baik fisik dan metafisik, namun keduanya mempunyai distingsi yang berbeda secara mendasar dalam proses identifikasi, pemaknaan, dan menarik kesimpulan. Keduanya menganalisis setiap kejadian secara inferensial sedangkan hati mengamati objek kajian secara presensial. Oleh karena itu,

${ }^{24}$ Al Faruqi, 44.

${ }^{25}$ Kartanegara, Mengislamkan Nalar: Sebuah Respon Terhadap Modernitas.

${ }^{26}$ A Q A Azizy, Pengembangan Ilmu-Ilmu Keislaman (Jakarta: Direktorat Perguruan Tinggi Agama Islam, Departemen Agama RI, 2003).

${ }^{27}$ Abu Bakar Madani, "Pemikiran Filsafat Al-Kindi", Lentera 17, no. 2 (2015). 110

${ }^{28}$ Achmad Khudori Soleh, "Mencermati Konsep Islamisasi Ilmu Ismail R Faruqi," Ulul Albab 12, no. 1 (2011). 
metode intuitif dapat menjembatani dan melintasi perbedaan yang lebar antara peneliti dengan objek penelitian. ${ }^{29}$

Mulyanto mengatakan bahwa islamisasi ilmu pengetahuan merupakan implementasi nilainilai Islam dalam struktur ilmu pengetahuan modern. Kemudian peneliti menentukan studi lanjutan atas ilmu pengetahuan yang telah dipilah dan dipilih. Peneliti menggunakan kriteria etis sebagai sumber rujukan karena ilmu pengetahuan diasumsikan bebas nilai. ${ }^{30}$

Haidar Bagir juga menekankan urgensi islamisasi ilmu pengetahuan. Ia mengemukakan bahwa perlunya dibentuk sains yang Islami. Ia mendasarkan pada argumennya yakni. Pertama, ilmu pengetahuan yang berkembang saat ini tidak dapat memenuhi kebutuhan umat Islam dalam hal material dan spiritual. Sistem sains yang ada tidak mampu mengantarkan seseorang pada keyakinan akan kekuasaan Allah Swt. Kedua, perbedaan kondisi sosiologis dan letak geografis antara barat dan timur yang berbeda. Hal ini berimplikasi dengan model ilmu pengetahuan yang dikembangkan. Ilmu pengetahuan harus mempertimbangkan kebutuhan masing-masing masyarakat. Ketiga, keberhasilan cendekiawan muslim di masa silam dalam memajukan sains merupakan bukti bahwa Islam mampu menghadirkan ilmu pengetahuan yang sesuai dengan nilai serta kebutuhan umat Islam. Kondisi ini pada akhirnya akan mengantarkan umat pada terciptanya peradaban yang islami. ${ }^{31}$

Lebih lanjut, Kartanegara juga menegaskan bahwa islamisasi ilmu pengetahuan penting dilakukan. ${ }^{32}$ Ia menilai perkembangan ilmu modern telah terbukti menimbulkan problem serius jika diabaikan khususnya dalam bidang teologi. Paradigma Barat telah mendorong sebuah perkembangan ilmu pengetahuan parsial yang hanya menekankan dunia indrawi sebagai realitas seperti tercermin dalam materialisme, sekularisme, dan positivisme. Mereka menolak realitas metafisik (baca : Tuhan) dan segala aspek objek gaib yang telah diajarkan Islam.

Letak perbedaan di antara pendapat di atas dapat disimpulkan terletak dalam pendekatannya. Terdapat kesan gengsi bagi kelompok yang berpendapat islamisasi ilmu pengetahuan tidak perlu dilakukan karena dalam prosesnya mengambil ilmu pengetahuan modern barat kemudian diislamisasikan. Kolompok ini menginginkan membentuk dan mengembangkan ilmu pengetahuan yang didasarkan pada corak dan sifat ajaran Islam.

Sementara bagi kelompok yang setuju islamisasi ilmu pengetahuan memandang bahwa mengembalikan fungsi sains pada fitrahnya merupakan hal penting. ${ }^{33}$ Segala sesuatu yang ada di dunia adalah milik Allah Swt. Sudah selayaknya para cendekiawan muslim meluruskan sains tersebut. Selain itu, tidak ada salahnya umat Islam mengadopsi perkembangan sains Barat. Tidak ada halangan bagi siapapun yang ingin mengembangkan ilmu pengetahuan sebagaimana dahulu para ilmuwan Barat juga mengambil khazanah ilmu pengetahuan Islam kemudian dikembangkan dengan penyesuaian konsep-konsep ajaran agama di Barat.

\footnotetext{
${ }^{29}$ Kartanegara, Mengislamkan Nalar: Sebuah Respon Terhadap Modernitas.

${ }^{30}$ Mulyanto, "Islamisasi Ilmu Pengetahuan," dalam Moeflich Hasbullah, Gagasan dan Perdebatan Islamisasi Ilmu Pengetahuan, (Jakarta: LSAF, Liris, Cidesindo, 2000), cet. I, hal. 17-18

${ }^{31}$ Haidar Bagir, Muslich Hasbullah dalam Nata, Metodologi Studi Islam.

${ }^{32}$ Kartanegara, "Islamisasi Ilmu Pengetahuan Dan Telaah Kritis Terhadap Epistemologi Barat."

${ }^{33}$ Salafudin, Islamisasi Ilmu Pengetahuan, (Pekalogan : Forum Tarbiyah Vol. 11 no. 2, 2013) 200
} 


\section{Pendekatan Islamisasi Ilmu Pengetahuan}

Visi agama Islam harus terejawantahkan dalam proses pendidikan. Al-Faruqi menegaskan bahwa sistem pendidikan yang sudah ada saat ini belum menunjukkan hal tersebut. Ia berpendapat bahwa telah terjadi westernisasi ilmu pengetahuan dalam dunia Islam. ${ }^{34}$ Pendidikan terdikotomi menjadi dua kutub yang saling memiliki orientasi berbeda yakni pendidikan agama dan sains modern. Sekularisme pendidikan ini pada akhirnya menjadikan ilmu pendidikan tidak sempurna. Dualisme pendidikan harus ditiadakan. Islam tidak mengenal adanya pemisahan antara agama dan sains.

Menurut Al-Faruqi, prinsip ketauhidan dalam Islam harus diterapkan dalam ilmu pengetahuan. Allah Swt. adalah sumber dari segala hal sehingga tidak ada sesuatu apapun yang terpisah atau tidak berhubungan dengan-Nya. Konsep ketauhidan bagi Al-Faruqi adalah keesaan, kesatuan ciptaan, integrasi kebenaran dan pengetahuan, hidup, serta sejarah. Keesaan bermakna kesadaan bahwa tiada Tuhan selain Allah. Dia adalah pencipa alam semesta. Dalam kaitannya dengan pengetahuan, pemahaman ini berimplikasi bahwa ilmu pengetahuan yang dikembangkan oleh manusia seharusnya digunakan untuk memahami realitas integral yakni utuh dan tak terpisah. Segala yang ada di jagat semesta tidak dapat lepas dari kuasa-Nya. Konsep ini berimplikasi pada esensi ilmu pengetahuan yang harus berorientasi pada kesatuan antara objek kajian dengan ketetapan Allah Swt. ${ }^{35}$

Kesatuan ciptaan merupakan kesadaran manusia bahwa fisik, psikis, ruang, waktu, dan segala ciptaan-Nya merupakan sistem kesatuan terpadu. Setiap unsur saling terikat dan terkait dengan satu tujuan akhir yakni Allah Swt. Pada satu sisi, manusia diberi kekuatan untuk mengelolanya dan di sisi lain, Allah menundukkan semesta kepada manusia sehingga dapat mengambil manfaat demi kesejahteraan kehidupan. Berlandaskan prinsip ini maka ilmu pengetahuan harus digunakan sebagai refleksi atas keyakinan (iman) dan bentuk ibadah kepadaNya. Berbeda dengan Barat yang meletakkan entitas manusia sebagai tujuan utama ilmu pengetahuan dan mengesampingkan Tuhan. Mereka telah memisahkan spirit spiritual dalam setiap kegiatan ilmiah. Arah pengembangan ilmu pengetahuan murni digunakan untuk mencapai kepentingan diri sendiri.

Kesatuan kebenaran dan pengetahuan. Kebenaran bersumber pada kajian mendalam pada setiap realitas Sunnatullah dan setiap kejadian bersumber dari asal yang sama, Allah Swt. Pemahaman ini mengantarkan manusia pada dua kesadaran penting yakni pertama, kebenaran tidaklah tunggal. Sebuah realitas dapat dilihat dari berbagai sudut pandang yang memungkinkan memiliki nilai kebenaran berbeda. Tentu kebenaran yang tidak keluar dari semangat ilahiyah. Hal ini merupakan salah satu bentuk sifat rahmat Allah Swt. kepada manusia agar mereka menjalani kehidupan dengan bahagia dan bijaksana. Kedua, wahyu yang merupakan pesan tuhan dan realitas alam semesta tidak mungkin berbeda bahkan bertentangan karena keduanya memiliki sumber yang sama yakni Allah Swt. Wahyu merupakan bentuk pedoman hidup yang telah Allah Swt. berikan kepada manusia. Ia berisi panduan untuk mengetahui, memahami, menyikapi, dan bertindak atas hukum sebab akibat yang telah Dia ciptakan. Oleh karena itu, seseorang tidak

${ }^{34}$ Firda Inayah, "Islamisasi Ilmu Pengetahuan : Prinsip Umum Dan Rencana Kerja Islam Raji Al-Faruqi," Kalimah: Jurnal Studi Agama Dan Pemikiran Islam 18, no. 2 (2020): 226-47.

${ }^{35}$ Nur Wahyu Hermawati, "Konsep Ilmu Berlandasakan Tauhid Ismail Raji Al-Faruqi Serta Implikasinya Di Dunia Pendidikan," At-Ta'dib 10, no. 2 (2015). 394 
diperbolehkan merumuskan klaim kebenaran yang paradosial dengan wahyu. Jika hal ini terjadi maka hendaknya ia menguji kembali pemahamannya atas teks agama dan data-data penelitian.

Integrasi pengetahuan berkait erat dengan keterpaduan antara 'aql (logika) dan naql (suprarasional) - yang sementara orang menyebutnya sebagai irrasional. Kesadaran manusia dalam memetakan ilmu pengetahuan yang terbagi menjadi ilmu pengetahuan yang diusahakan ('ilm kasb) dan ilmu pengetahuan pemberian tuhan seperti wahyu dan ilham (taken for granted). Pemahaman ini akan membawa seseorang untuk tidak terjebak pada pemilahan sementara pakar yang menyatakan terdapat disiplin ilmu yang bersifat ilmiah dan universal namun di kali lain harus diterima dengan keyakinan tanpa pertimbangan benar dan salah dan bersifat relatif.

Integrasi hidup terkait dengan tujuan penciptaan makhluk hidup yang memiliki tujuan utama sebagaimana firman Allah Swt.:

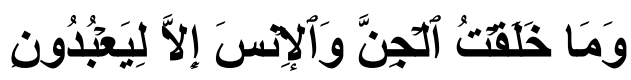

"Dan Aku tidaklah menciptakan jin dan manusia melainkan supaya mereka beribadah kepada-Ku.” (QS. adz-Dzariyat: 56)

Dengan memahami dan menyadari tujuan hidup maka akan berimplikasi pada kesatuan nilai pengetahuan yakni nilai ketuhanan. Agama adalah tuntunan serta dasar pijakan dalam setiap langkah manusia di dunia, sehingga usaha dalam mengembangkan ilmu pengetahuan selayaknya selaras dengan konsep Islam. Sudah seyogyanya material dan spiritual, jasmani dan ruhani, serta duniawi dan ukhrawi selalu berjalan beriringan dengan saling melengkapi satu dengan yang lain. Di sisi lain, kesatuan sejarah terkait erat dengan kesadaran kesatuan solidaritas manusia. Kaum muslim tidak disebut sebagai negara, bangsa, atau suku, namun umat yang universal. Keyakinan bahwa manusia yang kaffah adalah individu yang mengabdikan diri pada kesejahteraan umat. Umat memiliki pengertian trans lokal, non bounderies, tidak memiliki batas teritori geografis, etnis, budaya, dan lainnya. Perbedaan hanya ditentukan oleh takwa. Pada akhirnya pengembangan kesatuan ilmu pengetahuan dan sains modern harus berdasar atas asas kebermanfaatan bersama. Ilmu tidak boleh diarahkan untuk kepentingan dan keuntungan pribadi, kelompok, etnis, atau bangsa tertentu.

Al-Faruqi memaknai ilmu pengetahuan harus dibangun dengan paradigma yang berlandaskan konsep ajaran Islam. Dalam Islam, perkembangan keilmuan seseorang harus berbanding lurus dengan perkembangan keimanan. Jika tidak demikian maka individu tersebut akan semakin jauh dengan Tuhan. ${ }^{36}$ Dalam mewujudkan cita-cita luhur tersebut, Al-Faruqi merumuskan tiga cabang konsep sebuah ilmu pengetahuan yakni ontologis (konsep tentang apa), epistemologis (bagaimana cara) dan aksiologis (aspek nilai) agar tidak terlepas dari spirit Islam. Hal ini bukanlah perkara yang mustahil dilakukan. Intelektual muslim klasik telah membuktikan penguasaan tersebut melalui karya-karyanya.

Al-Faruqi telah merumuskan langkah sistematis yang perlu dilakukan oleh ilmuwan muslim dalam rangka islamisasi ilmu pengetahuan yakni:

${ }^{36}$ Nur Wahyu Hermawati, "Konsep Ilmu Berlandasakan Tauhid Ismail Raji Al-Faruqi Serta Implikasinya Di Dunia Pendidikan," At-Ta'dib 10, no. 2 (2015). 
1. Kemampuan pengetahuan ilmu modern: menguasai proses kategorisasi keilmuan. Pada langkah pertama ini, peneliti melakukan upaya pemetaan konsep definisi, metode, prinsip, kategori, tema, dan masalah. Uraian penjelasan dapat mendeskripsikan disiplin ilmu tertentu.

2. Menentukan batasan disiplin ilmu. Pada langkah ini, ilmu sains modern dirumuskan menjadi skema yang menjelaskan sejarah, pertumbuhan dan perkembangan metodologi, ruang lingkup, serta hipotesis yang diajukan oleh para tokoh pendukungnya. Bibliografi karyakarya induk dalam disiplin ilmu yang mencantumkan statemen penutup sementara tentang sebuah ilmu pengetahuan. Langkah kedua ini dapat memperjelas kelebihan dan kekurangan ilmu tersebut sehingga akan membentuk pemahaman bersama yang pada akhirnya mempermudah pemetaan dalam melakukan islamisasi ilmu pengetahuan.

3. Pemahaman komprehensif khazanah atau turats Islam. Pada tingkat ketiga ini akan mengurai hubungan antara konsep Islam dengan objek material maupun formal sebuah ilmu pengetahuan. Proses ini penting dilakukan untuk mengetahui bagaimana pandangan Islam terhadap bahasan ilmu. Terdapat kemungkinan bahwa ilmuwan Barat tidak mengetahui khazanah ilmiah Islam sehingga dapat mendistorsi keutuhan sebuah ilmu pengetahuan.

4. Tahapan yang berikutnya adalah analisis. Ilmuwan muslim dituntut untuk dapat melakukan telaah atas berbagai bagian serta hubungan antar bagian agar mendapatkan pemahaman makna secara menyeluruh. Langkah ini dimulai dengan kajian turats Islam berupa latar historis sebuah peristiwa meliputi kondisi sosial, politik, ekonomi, dan budaya serta keterkaitannya dengan berbagai bidang kehidupan manusia. Dalam melakukan penelaahan ilmu, perlu merumuskan skala prioritas seperti prinsip pokok, masalah, dan tema yang memiliki relevansi strategis dengan permasalahan kekinian penelitian dan pendidikan Islam. Melalui langkah ini, para ahli dapat mengetahui sejauh mana jangkauan konstruksi khazanah Islam menyentuh permasalahan yang dihadapi umat manusia sesuai konteks jamannya.

5. Menentukan hubungan antara konsep Islam dengan disiplin ilmu pengetahuan yang sedang dikaji.

6. Melakukan analisis kritis ilmu sains modern terhadap perkembangan permasalahan kekinian.

7. Melakukan penelitian terhadap masalah yang sedang dihadapi umat Islam. Al-Faruqi menekankan pentingnya memahami problem ekonomi, sosial, dan politik seperti pendidikan karakter yang lemah, pemerintahan yang tidak efektif, dan korupsi. ${ }^{37}$

8. Melakukan telaah terhadap kondisi permasalahan yang sedang dihadapi umat manusia.

9. Melakukan analisis lanjutan dari tahap sebelumnya dan sintesis.

10. Melakukan sinergi antara konsep ilmu sains modern dengan konsep ajaran Islam. Menuangkan gagasan tersebut menjadi buku ajar untuk perguruan tinggi. Pada tahap ini, para cendekiawan muslim dituntut untuk menggunakan daya kreatifitas dan inovasi yang dimiliki

${ }^{37}$ Budiman Prastyo, "Stages Of Islamization Of Science According To Ismail Raji Al-Faruqi As Unity Of Sciences Efforts And Implementation In The Practical Guidance Of Chemistry," Unnes Science Education Journal 7 , no. 1 (2018). 
guna menjembatani gap antara idealitas luhur konsep Islam dengan realitas permasalahan yang dihadapi umat manusia. ${ }^{38}$

11. Melakukan seminar dengan tujuan menyebarluaskan konsep yang diislamisasikan

Dalam proses percepatan gagasan islamisasi ini masih diperlukan media lain, yakni konferensi, seminar, lokakarya, dan pembinaan. Pada dasarnya, upaya yang dilakukan adalah mengadakan sintesis kreatif antara turats Islam dengan khazanah Barat. Untuk mencapai hal tersebut, umat Islam harus menguasai khazanah klasik, menelaah secara kritis perkembangan ilmu pengetahuan barat dengan perspektif Islam, dan merumuskan disiplin keilmuan baru yang utuh, terpadu serta tidak dikotomis.

Namun gagasan yang dikemukakan oleh Al-Faruqi tidak lepas dari kritik pakar lain. Di sisi lain, Al-Attas juga menjelaskan proses yang harus dilakukan oleh cendekiawan muslim dalam islamisasi ilmu pengetahuan yakni ${ }^{39}$ :

1. Menentukan konsep keilmuan yang menjadi dasar perkembangan ilmu pengetahuan barat khususnya ilmu-ilmu yang berkaitan dengan nilai-nilai kemanusiaan seperti sejarah, filsafat, seni, sastra, agama, dan lain sebagainya. Pada tahap ini, diperlukan sinergi antara perkembangan keilmuan humaniora dan sains modern dengan ajaran-ajaran Islam. Hasil sintesis tersebut harus menunjukkan tidak ada pertentangan antar keduanya. Untuk memastikan hal tersebut, diperlukan kajian secara mendalam melingkupi konstruksi keilmuan khususnya aspek ontologi, epistemologi, dan aksiologi. Pandangan dunia terkait keabsahan realitas yang terbentuk secara dikotomis seperti sekularisme perlu ditinjau ulang. Penerapan empirisme dengan menafikan metode pencarian kebenaran dari sumber lain juga memerlukan kajian lebih lanjut. Bagi ilmuwan muslim, pencarian titik temu harus menjadi prime priority dengan melakukan sintensis world view barat dengan konsep Islam yang mempercayai kebenaran di balik apa yang ditangkap oleh penca indra.

2. Setelah menentukan batas keilmuan barat yang sekular, cendekiawan muslim melakukan proses integrasi ilmu pengetahuan (unity of sciences). Konsep Islam yang perlu dijadikan patokan dalam integrasi tersebut di antaranya hakikat penciptaan manusia sebagai khalifah di bumi, agama, ilmu, hikmah, konsep makrifat, keadilan, etika atau akhlak dalam Islam, dan konsep perguruan tinggi.

Al-Attas menjelaskan bahwa anggapan sementara pakar yang menyangsikan islamisasi ilmu pengetahuan sebagai proses labelisasi ilmu adalah tidak benar. ${ }^{40}$ Konsep ilmu pengetahuan Barat secara bertahap akan dilakukan rekonstruksi dengan konsep unity of sciences. Perkembangan ilmu pengetahuan akan semakin terarah sesuai dengan tuntunan Al-Qur'an, sunnah, dan ijmak ulama.

Dengan seperti itu, umat Islam dapat mempelajari ilmu pengetahuan secara menyeluruh tanpa risiko berupa kesesatan dan kekeliruan. Ilmu pengetahuan akan berada pada jalur yang hakiki di mana dapat mengantarkan seseorang kepada bertambahnya keyakinan dan keimanan

\footnotetext{
${ }^{38}$ Poppy Rachman, "Implikasi Konsep Islamisasi Ilmu Pengetahuan Ismail Raji Al-Faruqi,” HUMANISTIKA: Jurnal Keislaman 6, no. 2 (2020): 154-70.

${ }^{39}$ Muhammad Taufik and Muhammad Yasir, "Mengkritisi Konsep Islamisasi Ilmu Ismail Raji Al-Faruqi: Telaah Pemikiran Ziauddin Sardar,” Jurnal Ushuluddin 25, no. 2 (2017): 109-23.

${ }^{40}$ M Ghufron, "ISLAMISASI ILMU PENGETAHUAN (Perspektif Sejarah, Kontroversi Dan Perkembangannya)," Jurnal Urwatul Wutsqo 1, no. 1 (2012).
} 
kepada Allah Swt. Outcome learning peserta didik akan menjadi insan paripurna dimana ia dapat memahami melalui kajian ilmu yang dipelajari pada konsep-konsep Islam khusunya tujuan penciptaan manusia sebagai abdi kepada Allah Swt. ${ }^{41}$

Sementara Abuddin Nata bependapat dalam bukunya Metodologi Studi Islam bahwa pendekatan yang dapat dilakukan dalam proses islamisasi ilmu pengetahuan adalah empat hal sebagai berikut ${ }^{42}$ :

Pertama, dalam proses integrasi ilmu pengetahuan, Islam dapat digunakan sebagai dasar aspek aksiologi. Nilai-nilai ajaran Islam dimasukkan dalam struktur keilmuan sains modern, sedangkan dalam aspek epistemologi dan ontologi tetap dalam kondisi sesuai yang telah ditetapkan ilmu tersebut tanpa ada yang perlu dipermasalahkan. Abuddin menekankan peran penting individu yang menggunakan ilmu tersebut. Abuddin mengasumsikan ilmu pengetahuan merupakan konsep netral dan bebas nilai sehingga dalam implementasi keilmuan, etika Islam dapat terlihat baik secara lahir maupun batin.

Untuk mencapai pemahaman keagamaan yang paripurna, perpaduan ilmu pengetahuan dan sains modern dengan bidang keahlian masing-masing seseorang adalah penting. Secara subtansial, islamisasi ilmu pengetahuan memiliki prinsip sebagai berikut:

a. Seseorang harus memiliki komitmen yang tinggi untuk mengamalkan ajaran dan nilai-nilai keagamaan secara teguh dan konsisten. Niat memiliki peran penting dalam Islam karena setiap amal perbuatan memiliki nilai ukhrawi jika dikaitkan dengan Allah Swt., sehingga proses islamisasi ilmu pengetahuan dapat dengan lancar dan mudah dilaksanakan.

b. Integrasi ilmu pengetahuan dapat diwujudkan dengan langkah memasukan konsep etika atau akhlak pada sains modern. Ilmu pengetahuan diasumsikan tidak bebas nilai. Seseorang dapat memasukkan nilai Islam pada kontruksi keilmuan. Langkah ini dapat dinilai sebagai cara untuk mengentaskan umat dari kelemahan dan kesesatan akidah.

Kedua, melakukan redefinisi konsep tauhid dengan ruang lingkup yang lebih luas. Tauhid tidak hanya dipahami secara teologi yakni meyakini akan keesaan, kekuasaan, dan kesempurnaan sifat-sifat Allah Swt. Lebih dari itu, tauhid dimaknai sebagai perwujudan kesatuan dan sinergi antar sesama manusia, manusia dan alam, serta manusia dengan seluruh ciptaan Allah Swt.

Melalui konsep tauhid tersebut, secara filosofis integrasi ilmu pengetahuan dapat diimplementasikan dengan epistemologi dan ontologi. Secara epistemologi, sebuah ilmu pengetahuan agama dapat mengadopsi metode ijtihadiyah sesuai dengan konsep operasional yang telah ditentukan oleh pakar hukum Islam. Untuk kajian ayat kauniyah, dapat menggunakan metode eksperimental di laboratorium, sedangkan metode observasi dapat dilakukan untuk mengkaji interaksi sosial yang terdapat dalam fenomena keseharian masyarakat. Metode ini nantinya menghasilkan kajian antroposentris seperti ilmu ekonomi, ilmu politik, ilmu komunikasi, ilmu sosiologi dan lain-lain.

Sementara dengan melalui pendekatan ontologi, ilmu pengetahuan dapat mengambil ayatayat Al-Qur'an maupun hadist sebagai sumber. Dalam salah satu firmannya, Allah Swt. memerintahkan manusia untuk melihat, merenung, mengamati, dan meneliti semua ciptaan-Nya.

\footnotetext{
${ }^{41}$ Solichin, "Islamisasi Ilmu Pengetahuan Dan Aplikasinya Dalam Pendidikan Islam."

${ }^{42}$ Nata, Metodologi Studi Islam.
} 
Konsep tafakkur dalam Al-Qur'an dapat dilihat dari beberapa ayat seperti Ar-Rum ayat 8, AnNahl ayat 65-66, dan Saba' ayat 9. Metode ini pada akhirnya dapat menghasilkan sebuah kajian keilmuan yang memberikan kesadaran kepada manusia bahwa pada hakikatnya semua yang ada di muka bumi berasal dari Allah Swt.

Kemajuan peradaban Islam pernah dicapai melalui model islamisasi ilmu pengetahuan seperti ini pada zaman klasik. Cendekiawan muslim yang integrated. Ilmuwan muslim pada waktu itu telah membuktikan bahwa dirinya tidak hanya memiliki kemampuan pemahaman keagamaan yang mumpuni, namun juga penguasaan sains yang gemilang seperti Ibnu Sina, Ibnu Rusyd, dan al-Razi. Sejarah telah membuktikan bahwa islamisasi ilmu pengetahuan bukanlah sebuah ide utopis yang sulit direalisasikan. Namun gagasan tersebut merupakan langkah yang terukur dan mampu untuk dilakukan.

Ketiga, proses integrasi keilmuan dapat dilakukan dari inisiatif pribadi. Seseorang tidak perlu menunggu sebuah institusi terstruktur yang secara khusus menangani ini. Pembelajaran dilakukan secara bertahap dan kontinu. Pada praktiknya, ilmu umum yang sudah unity of sciences dapat diajarkan kepada orang lain. Sebagai langkah awal, seseorang dapat mendalami keilmuan agama terlebih dahulu dan selanjutnya mengkombinasikannya dengan keilmuan sains modern sesuai dengan kecenderungan masing-masing. Langkah ini merupakan bentuk pemetaan peserta didik dalam proses islamisasi ilmu pengetahuan tanpa melakukan struktur kurikulum yang ada.

Keempat, perbedaan antara paradigma agama yang taken for granted dengan ilmu pengetahuan sains modern harus diperkecil dengan mempertemukan titik kesamaannya. Agama yang dianggap sebagai sumber kebenaran yang pasti, transendental, dan absolut harus dipadukan dengan sains modern yang bersifat relatif, tak pasti, dan spekulatif. Sinergi yang dapat dilakukan untuk mempertegas langkah tersebut antara lain:

a. Dinamika pemikiran Islam dapat berjalan dengan baik dengan cara melakukan sinergi antara paradigma agama yang absolut dengan ilmu pengetahuan yang relatif. Kebenaran mutlak agama memerlukan penjabaran pemikiran manusia. Namun perlu disadari bahwa dalam menjelaskan konsep-konsep agama, pemikiran manusia terbatas.

b. Segala sesuatu yang ada di muka bumi ini adalah perwujudan dari kekuasaan Tuhan. Meski penemuan ilmu pengetahuan manusia modern sangat canggih, namun harus disertai kesadaran bahwa perkembangan tersebut merupakan anugrah Allah Swt. Relatifitas dan spekulatif ilmu pengetahuan tidak perlu dipertentangkan dengan agama yang bersifat pasti dan transendental.

c. Manusia membutuhkan bimbingan Tuhan dalam menjalani hidup di dunia. Termasuk ketika meneliti ilmu pengetahuan karena keterbatasan kemampuan manusia dalam menangkap perwujudan kekuasaan Allah Swt. yang ditunjukkan melalui alam semesta.

d. Objektifitas ilmu yang melihat segala sesuatu sebagaimana adanya dan normatifitas agama yang melihat sesuatu dengan bagaimana seharusnya merupakan paradigma yang tidak perlu dipertentangkan. Pemikiran normatif dapat dijelaskan secara objektif agar tampak dalam realitas, sedangkan pemikiran objektif membutuhkan tuntunan normatif agar tidak salah arah dan bernilai.

e. Problem solving yang ditawarkan ilmu pengetahuan melalui rasionalitas manusia dan solusi yang diberikan agama melalui petunjuk tuhan merupakan dua kutub yang tidak perlu 
dipertentangkan. Agama memandang rasio sebagai pemberian tuhan yang harus disyukuri dan dihargai. Begitu pula petunjuk Tuhan merupakan jalan pintas yang dapat digunakan untuk memecahkan suatu permasalahan.

\section{Kesimpulan}

Langkah-langkah teknis dalam upaya islamisasi ilmu pengetahuan, Al-Faruqi memberikan rincian sebagai berikut; yaitu penguasaan disiplin ilmu modern, survei disiplin ilmu, sebuah antologi, tahap analisa, penentuan relevansi Islam terhadap ilmu, perkembangannya di masa kini, survei permasalahan kontemporer, meninjau problem yang dihadapi manusia, analisis kreatif dan sintesis, mengintegrasikan kembali disiplin ilmu modern dalam kerangka Islam, serta mendistribusikan hasil islamisasi ilmu pengetahuan.

Berbeda dengan pandangan Al-Attas, terdapat dua proses yang harus dilalui dalam islamisasi ilmu pengetahuan yaitu: merekonstruksi keilmuan sains modern dengan memisahkan konsep-konsep dan unsur-unsur kunci yang membentuknya terutama ilmu pengetahuan humaniora dan memasukkan nilai-nilai Islam yang telah disesuaikan dengan keilmuan modern tersebut.

Pakar lain, Abuddin Nata, bependapat bahwa proses unity of sciences dapat dilakukan dengan cara: Pertama, Islam digunakan sebagai dasar landasan dalam islamisasi ilmu pengetahuan. Kedua, dengan pendekatan subtansial. Ketiga, redefinisi dan implementasi konsep tauhid dalam makna yang lebih luas. Keempat, inisiatif pribadi dengan mengikuti jenjang pendidikan secara bertahap dan kontinu. Struktur kurikulum berperan penting dalam proses ini sehingga seseorang dapat menentukan dengan memilihnya sesuai kebutuhan. Kelima, menemukan titik temu antara paradigma keilmuan sains modern dengan agama. Sains barat yang mengedepankan empirisme dan rasionalitas dapat bersinergi dengan tuntunan agama yang bersifat religius, intuitif, dan suprarasional.

Gagasan islamisasi ilmu pengetahuan merupakan jawaban atas kondisi umat Islam yang tertinggal dengan Barat. Usaha ini adalah upaya dalam meraih kejayaan yang pernah dicapai pada masa silam. Para pemikir muslim harus dapat menjawab tantangan zaman dengan selalu menampilkan Islam sebagai agama yang paripurna.

Selain itu, konsep islamisasi ilmu pengetahuan secara tersirat menggambarkan kegelisahan cendekiawan muslim dalam melihat perkembangan keilmuan modern Barat yang kering dari nilai-nilai agama. Konsep ilmu perlu dikembalikan pada fitrahnya agar dapat berfungsi sesuai dengan tuntunan agama. Islam sangat mendorong umatnya dalam mencari ilmu. Bahkan Allah Swt. telah menjanjikan akan meningkatkan derajat seseorang yang berilmu. Tentu konsep ini tidak akan tercapai jika perkembangan ilmu pengetahuan jauh dari nilai ketuhanan. Dalam hal ini, para cendekiawan muslim telah merumuskan paradigma baru tentang keilmuan yang mendorong umat Islam dalam melakukan penelitian dan pengembangan sains modern. Langkah integrasi keilmuan perlu mendapatkan perhatian dan dukungan dari semua kalangan khususnya umat muslim agar ajaran Islam dapat terwujud dalam kehidupan nyata. 


\section{Referensi}

Al-Attas, Naquib, Islam dalam sejarah dan Kebudayaan Melayu. Bandung : Mizan, 1990

Azizy, A Q A. "Pengembangan Ilmu-Ilmu Keislaman". Jakarta : Direktorat Perguruan Tinggi Agama Islam, Departemen Agama RI, 2003.

Daud, Wan Mohd Nor Wan, Filsafat dan Praktik Pendidikan Islam, Syed M. Naquib al-Attas Bandung : Mizan, 2003

Ghufron, M. "Islamisasi Ilmu Pengetahuan (Perspektif Sejarah, Kontroversi Dan Perkembangannya).” Jurnal Urwatul Wutsqo 1, no. 1 (2012).

Hanifah, Umi. "Islamisasi Ilmu Pengetahuan Kontemporer (Konsep Integrasi keilmuan Di Universitas-Universitas Islam Indonesia." TADRIS: Jurnal Pendidikan Islam 13, no. 2 (2018): 273-94.

Hasbullah, Moeflich. "Gagasan dan Perdebatan Islamisasi Ilmu Pengetahuan”, Jakarta: LSAF (2000)

Hermawati, Nur Wahyu. "Konsep Ilmu Berlandasakan Tauhid Ismail Raji Al-Faruqi Serta Implikasinya Di Dunia Pendidikan.” At-Ta'dib 10, no. 2 (2015).

Hidayat, Taufik, Konsep Berpikir (Al-Fikr) Dalam Al-Quran dan Implikasinya Terhadap Pembelajaran PAI di Sekolah (Studi Tematik tentang Ayat-Ayat yang Mengandung Term al-Fikr), Tarbawy 3, no.1, (2016)

Inayah, Firda. "Islamisasi Ilmu Pengetahuan : Prinsip Umum Dan Rencana Kerja Islam Raji AlFaruqi." Kalimah: Jurnal Studi Agama Dan Pemikiran Islam 18, no. 2 (2020)

Kartanegara, Mulyadhi. "Islamisasi Ilmu Pengetahuan Dan Telaah Kritis Terhadap Epistemologi Barat.” Jurnal Refleksi 1, no. 3 (1999).

_. Mengislamkan Nalar: Sebuah Respon Terhadap Modernitas. Erlangga, 2007.

Kuntowijoyo. Islam sebagai Ilmu Epitemologi, Metodologi, dan Etika, Yogyakarta: Tiara Wacana, 2006.

Madani, Abu Bakar, "Pemikiran Filsafat Al-Kindi”, Lentera 17, no 2 (2015).

Mukhlis, Febri Hijroh. "Integrasi-Interkoneksi keilmuan Prof. Amin Abdullah: Kesalingterkaitan Antara Ilmu-Ilmu Agama Dan Science.” Al-Adabiya: Jurnal Kebudayaan Dan Keagamaan 13, no. 01 (September 3, 2018): 78-101. https://doi.org/10.37680/adabiya.v13i01.5.

Nasution, Harun. Ensiklopedi Islam Indonesia, Vol. I, Jakarta: Jambatan, 1992.

Nata, Abuddin. Metodologi Studi Islam. Jakarta: PT Raja Grafindo Pustaka, 2016.

Nivayani, Irma, "Islamisasi Ilmu Pengetahuan Menurut Pandangan Syed M. Naquib Al-Attas dan Impikasi Terhadap Lembaga Pendidikan International Institute of Islamic Thought Civilization (ISTAC)", Jurnal Al-Muta'aliyah 1 no. 1 (2017)

Prastyo, Budiman. "Stages Of Islamization Of Science According To Ismail Raji Al-Faruqi As Unity Of Sciences Efforts And Implementation In The Practical Guidance Of Chemistry." Unnes Science Education Journal 7, no. 1 (2018).

Putra, Aris Try Andreas, "Konsep Pemikiran Ismail Raji Al-Faruqi (Dari Tauhid Menuju Integrasi Ilmu Pengetahuan di Lembaga Pendidikan)", Zawiyah : Jurnal Pemikiran Islam 6 no 1 (2020)

Rachman, Poppy. "Implikasi Konsep Islamisasi Ilmu Pengetahuan Ismail Raji Al-Faruqi." HUMANISTIKA: Jurnal Keislaman 6, no. 2 (2020): 154-70. 
Salafudin, Islamisasi Ilmu Pengetahuan, Forum Tarbiyah 11, no. 2 (2013)

Sardar, Ziauddin. Sains, Teknologi, dan Pembangunan di Dunia Islam, Bandung: Penerbit Pustaka, 1989.

Shihab, M Quraish. Tafsir Al-Misbah: Pesan, Kesan Dan Keserasian Al-Quran. Jakarta: Lentera Hati, 2002.

Soleh, Achmad Khudori. "Mencermati Konsep Islamisasi Ilmu Ismail R Faruqi." Ulul Albab 12, no. 1 (2011).

Solichin, Mohammad Muchlis. "Islamisasi Ilmu Pengetahuan Dan Aplikasinya Dalam Pendidikan Islam." TADRIS: Jurnal Pendidikan Islam 3, no. 1 (2008).

Sugiyono. Memahami Penelitian Kualitatif, Bandung: Alfabeta, 2016.

Taufik, Muhammad, and Muhammad Yasir. "Mengkritisi Konsep Islamisasi Ilmu Ismail Raji AlFaruqi: Telaah Pemikiran Ziauddin Sardar.” Jurnal Ushuluddin 25, no. 2 (2017): 109-23.

Wahyuni, Fitri. "Islamisasi Ilmu Pengetahuan (Upaya Mengurai Dikotomi Ilmu Pengetahuan Dalam Islam)." QALAMUNA: Jurnal Pendidikan, Sosial, Dan Agama 10, no. 02 (2018). https://doi.org/10.5281/zenodo.3559251

Zuhdiyah, "Islamisasi Ilmu Ismail Raji Al-Faruqi”, Tadrib : Jurnal Pendidikan Agama Islam 2, no. 2 (2016) 